\title{
Debates
}

\section{Socially referenced medical education and market policies of quality regulation}

\section{Mara Regina Lemes De Sordi ${ }^{(a)}$}

<maradesordi14@gmail.com>

\author{
(a) Departamento de Ensino e Práticas \\ Culturais, Faculdade de Educação, \\ Universidade Estadual de Campinas. \\ Avenida Bertrand Russell, 801, \\ Cidade Universitária Zeferino Vaz. \\ Campinas, SP, Brasil. 13083-865.
}

Amidst a national conjuncture strongly characterized by the competitiveness, performativity and meritocracy ethos, it would be strange if public policies that cost so much to the population, such as education and health, were not ran over. It is about giving room to privatization without much embarrassment, taking away from the Brazilians (particularly the most socially weak ones) the right to have a dignified and safe future. We watch, still perplexed, but outraged, the dismantlement of our fragile democracy. How will we behave when faced with the discontinuities of the More Doctors Program (PMM) or, what is worse, with its pseudo-maintenance of convenient arrangements? One of the pillars that is most at risk is medical education. Consequently, so are its regulating public policies. The discontinuities that are already in progress foreshadow the future elimination of the recently implemented transformations.

In this perspective, reading the text by Chioro and colleagues was precious for two reasons. The first one was the rigor with which tense movements that follow and define a cycle of policies that challenge heavy and conservative structures, such as the ones in health, are 
regained. These are the characteristics of the hospital-centered model and the nonjustifiable justification of the concentration of medical courses in certain privileged regions of the country that remain despite the National Curricular Guidelines (2001 and 2014) statement that the Brazilian National Health System (SUS) is responsible for organizing health education. The arguments brought up by the authors reveal the distance and contradictions between what is approved and what is indeed implemented, highlighting the relevance of stronger regulation mechanisms evidenced in organically conceived programs negotiated in multiple instances. The second aspect that mobilized me was the non-neutrality stance taken by the authors when describing, analyzing and prospecting the repercussions of the changes in public policies that aimed at reorienting the medical education axis. Non-neutrality is not restricted to the scientific aspects of the text (as a researcher in the area). It is also inscribed in the way the authors adopt a protagonist role in political spaces by seeing themselves as committed health professionals in the fight for SUS, exercising a public management that is willing to incite and foster changes in teaching and practicing health. The inseparability of the values that follow us in our diverse ways of acting in different scenarios and exerting influence in micro and macro-decisions can be comprehended from this non-neutrality. Any concession or justification for not acting according to the values that guide our work deserves further clarification.

That being said, when faced with the historicity of health policies and the way regulation mechanisms implemented by the State evidence significant advances in an attempt to build a line of coherence among the different programs focused on medical education, we have to feel deeply sorry for the repercussions that approach when faced with the discontinuities of the programs and partnerships between the Brazilian Ministries of Health and of Education. The challenges in maintaining SUS do not prescind the challenges in reorienting the medical education axis and the education of other health professionals.

The National Curricular Guidelines enlightened the requirement of a curricular reform that would affect the doctor's profile required by SUS. They carefully indicated the need for a teaching-service integration, a primary care focused on education, the relevance of active learning methods and the impropriety of educating doctors not based on interprofessionality. They judiciously indicated the most purposeful partnerships between universities and health departments made through COAPES, among other things. They reinforced the need for quality assessment devices of medical courses to include specific dimensions and indicators of the area and to pay special attention to the specificity of the social commitment of future doctors in health services.

Understanding the change's sensibility fostered numerous programs and actions, including intersectoral ones, aiming at ensuring greater adherence of medical courses to new medical education requirements. If, at first, the focus aimed at affecting the supply and expansion of medical seats, the great change occurred in the way of understanding and establishing rules for this process, inverting the market logic as the indicator to open new courses to meet legitimate health demands of the population, particularly those located in remote and distant areas that do not interest education entrepreneurs. 
Socially committed public health policies, such as PMM, courageously showed it is possible to conceive, negotiate and implement certain ways of regulating medical education with their previous developments in the population's healthcare quality. However, in this field, prevaricating is dangerous.

There is an open field to disputes that affect the Brazilians' destiny concerning health as an inalienable right to be provided to all. The State is responsible for respecting constitutional accomplishments, such as SUS. In a complex and contradictory way, there was a certain time disjunction between the social accomplishments and the rules that would guide the State's action in defense of the population's health needs. This hiatus had the non-aloof help of part of the medical corporation, which strongly resisted to the advances of policies that induce changes in health education that would benefit exactly those who mostly need SUS or who depend exclusively on it for healthcare.

We astonishingly observed the increase of disturbing discourses disqualifying SUS and policies that induce changes in health education. It seems they were yet again authorized. These discourses against the new National Curricular Guidelines and that do not acknowledge (deny) PMM's advances are made by doctors and endorsed by their corporations. According to Ball, resorting to Foucault, considering politics as a discourse means thinking how "discourses are constructed and how they change, but also how they shape everyday existence, that is, in part at least, how they 'form the objects of which they speak"'1 (p. 2).

If we consider the repercussions of these conservative discourses strongly affected by the market ethos in the subjectivities of future doctors, we may be instilling/ reinforcing the lack of interest for Medicine as a social practice inserted in a country that lacks a human comprehensive care. We may be educating doctors that refuse to act in remote regions, taking away from so many Brazilians the sacred right to have access to a dignified and firm treatment.

However, as political agents, we can also surprise and overcome the imposed boundaries that deconstruct programs focused on an expanded, organically thought, executed and assessed medical education that revealed, within its time limits, its power. One of its success indicators was the fact that it provided a unique care experience to Brazilians. The increase in the number of programs, considering the achieved goals and the positive repercussions in the users' life, indicates stagnation risks, as evidenced in the text.

What would explain the unwillingness to engage this medical education model that analyzes the Brazilian population's health reality in an implied way? What would be behind the explicit or subliminal resistances that gained strength after 2016? Is there room for a propositional reaction ${ }^{2,3}$ to what Ball calls the terrors of performativity ${ }^{4}$, which end up affecting the subjectivity of what means being a professional in these dark times?

Now, more than ever, we need to react to this state of social conformity ${ }^{5}$ and politically act in our workspaces. Acknowledging the logics imposed by neoliberal policies imply fighting for overcoming a static and rational view of politics. According to Ball ${ }^{6}$, policies are determined in scenarios of social, economic, ideological, etc. disputes. For some time, the political discourse becomes hegemonic, but it will always be in dispute with other discourses present in these scenarios. 
We can reflect upon policies in terms of space and time, political trajectories, political movements with time and in different spaces. Policies have a similar trajectory to a rocket: they take off, travel over space and land. There are occasional accidents. Sometimes, they achieve something spectacular. However, they move through time and, sometimes, simply disappear ${ }^{7}$ (p. 306-7).

It seems to be necessary to admit that our accomplishments that were transformed into public health policies based on the population's interests suffered a strong shock. However, those that are subtly introduced and that worry us will not be linearly established. They will come across political agents in different spaces, committed to the common good and aware of their context of influence in the reality, who will certainly resist and fight for historical causes.

It is about reinventing emancipatory possibilities. Sometimes, a certain level of political-pedagogical disobedience to quality standards aimed at imposing ourselves in medical education can portray the civic courage ${ }^{8}$ we are willing to have in defense of our population's right to health.

\section{Copyright}

This article is distributed under the terms of the Creative Commons Attribution 4.0 International License, BY type (https://creativecommons.org/licenses/by/4.0/deed.en).

\section{References}

1. Ball S. What is policy? 21 years later: reflections on the possibilities of policy research. Discourse. 2015; 36(3):306-13.

2. Freitas LC. Os reformadores empresariais da educação e a disputa pelo controle do processo pedagógico na escola. Educ Soc. 2014; 35(129):1085-114.

3. Sordi MRL, Varani A, Mendes GSCV, organizadoras. Qualidade(s) da escola pública: reinventando a avaliação como resistência. Uberlândia: Navegando Publicações; 2017.

4. Ball S. Reformar escolas/reformar professores e os terrores da performatividade. Rev Port Educ. 2002; 15(2):3-23.

5. Sousa Santos B. Para uma pedagogia do conflito. In: Silva HL, Azevedo JC, Santos ES. Novos mapas culturais, novas perspectivas educacionais Porto Alegre: Sulina; 1996.

6. Ball S. Textos, discursos y trayectorias de la política: la teoria estratégica. Paginas. Rev Esc Cienc Educ. 2002; 3(2):19-33.

7. Mainardes J, Marcondes MI. Entrevista com Stephen Ball: um diálogo sobre justiça social, pesquisa e política educacional. Educ Soc. 2009; 30(106):303-18. 
(2)

8. Afonso AJ. Para uma conceptualização alternativa de accountability em educação.

Educ Soc. 2012; 33(119):471-84.

Translator: Caroline Luiza Alberoni

Submitted on $12 / 17 / 18$.

Approved on 01/04/19. 